\title{
The Profile of Glycated Hemoglobin in Non-Diabetic Pregnant Women with Preeclampsia: A Case-Control Study in Kinshasa, the Democratic Republic of Congo
}

\author{
Guelord Mukiapini Luzolo', Dophie Tshibuela Beya', Daddy Kabamba Numbi', \\ Passy Kimena Nyota1, Placide Cyanga Ngandu1, Blaise Sumbu Matondo Manzambi', \\ Aliocha Nkodila Natuhoyila², Mamy Ngole Zita1, Gustave Ilunga Ntita1, Mireille Nganga Nkanga ${ }^{1}$, \\ Jérémie Muwonga Masidi' ${ }^{1}$, Donatien Kayembe Nzongola-Nkasu', \\ Dieudonné Sengeyi Mushengezi³ ${ }^{3}$ Arsene Mputu Lobota ${ }^{3}$, Baudouin Buassa-Bu-Tsumbu ${ }^{4}$, \\ Cathy Ali Risasi ${ }^{4}$ Fons Verdonck ${ }^{5}$, Bernard Spitz ${ }^{6}$, Jean Pierre Elongi Moyene ${ }^{7 *}$
}

\footnotetext{
${ }^{1}$ Département de Biologie Médicale, Service de Biologie Clinique, Cliniques Universitaires de Kinshasa, Kinshasa, Congo

${ }^{2}$ Département de Médecine interne, Cliniques Universitaires de Kinshasa, Kinshasa, Congo

${ }^{3}$ Département de Gynécologie-Obstétrique, Cliniques Universitaires de Kinshasa, Kinshasa, Congo

${ }^{4}$ Département de Biologie Clinique, Hôpital Général de Référence de Kinshasa, Kinshasa, Congo

${ }^{5}$ Department of Physiology, KU Leuven, Belgium

${ }^{6}$ Department of Gynecology-Obstetrics, KU Leuven, Belgium

${ }^{7}$ Département de Gynécologie-Obstétrique, Hôpital Général de Référence de Kinshasa, Kinshasa, Congo

Email: mukiapiniguelord@gmail.com, dophiebeya@gmail.com, dagsdaddy23@gmail.com, passy.nkomba@gmail.com, cyanga2018@gmail.com, bsumat@yahoo.fr,nkodilaaliocha@gmail.com,mmyngole@gmail.com, ilungan75@hotmail.com, kayembe.donatien@gmail.com, pmuwonga@hotmail.com, mnganga2002@yahoo.fr, mireille.nganga@unikin.ac.cd, dsengeyi@gmail.com, arsenemputu@yahoo.fr, baudouin_buassa@yahoo.com,cathymulumba@yahoo.fr, fons.verdonck@kuleuven.be,bernard.spitz@kuleuven.be, *elongi2002@yahoo.fr
}

How to cite this paper: Luzolo, G.M., Beya, D.T., Numbi, D.K., Nyota, P.K., Ngandu, P.C., Manzambi, B.S.M., Natuhoyila, A.N., Zita, M.N., Ntita, G.I., Nkanga, M.N., Masidi, J.M., Nzongola-Nkasu, D.K., Mushengezi, D.S., Lobota, A.M., Buassa-Bu-Tsumbu, B., Risasi, C.A., Verdonck, F., Spitz, B. and Moyene, J.P.E. (2020) The Profile of Glycated Hemoglobin in Non-Diabetic Pregnant Women with Preeclampsia: A Case-Control Study in Kinshasa, the Democratic Republic of Congo. Open Journal of Obstetrics and Gynecology, 10, 365-389.

https://doi.org/10.4236/ojog.2020.1030034

Received: February 17, 2020

Accepted: March 20, 2020

Published: March 23, 2020

\begin{abstract}
Background: A disturbed glucose metabolism is quite common during pregnancy. It is due to the diabetogenic potential of pregnancy and responsible for many obstetric complications. The glycated hemoglobin is one of the markers used to depict these disorders. Higher concentrations of this marker would be associated with unfavorable results of pregnancy. Objective: To describe the profile of $\mathrm{HbAlc}$ in non-diabetic preeclamptic pregnant women and to establish the association between the values of this marker and the maternal and fetal complications. Materials and Method: This is a case-control study of 142 pregnant women in their second and third trimester. They were followed in the maternity hospitals of University Clinics and the General Reference Hospital in Kinshasa, Democratic Republic of Congo between May and October 2019. The sampling of preeclamptic pregnant women was exhaustive.
\end{abstract}


Copyright (C) 2020 by author(s) and Scientific Research Publishing Inc. This work is licensed under the Creative Commons Attribution International License (CC BY 4.0).

http://creativecommons.org/licenses/by/4.0/

Open Access
Controls were healthy pregnant women carrying pregnancies of the same type and of the same gestational age as the cases. Ultimately, 71 were preeclamptic and 71 healthy (controls). HbAlc was determined by immunoturbidimetry. Results: A total of 142 pregnant women took part in this study consisting of 71 preeclamptic women (cases) and 71 healthy pregnant women (controls). The average age of these pregnant women was $28.8 \pm 6.8(28.2 \pm$ 6.8 years vs $29.5 \pm 6.8$ years $p=0.559)$, with an average parity of $2.3 \pm 1.5$ (2.2 \pm 1.7 vs $2.4 \pm 1.2, \mathrm{p}=0.005$ ). The majority were carriers of monofoetal pregnancy. Higher HbAlc values were observed in the preeclamptic pregnant women compared to the controls $(5.7 \pm 1.3 \%$ vs $4.8 \pm 0.7 \%, \mathrm{p}<0.001)$. The proportion of pregnant women with pathological $\mathrm{HbAlc}$ values $(>5.6 \%)$ was also higher in the group of preeclamptic pregnant women $(46.5 \%$ vs $9.9 \%, \mathrm{p}<$ 0.001 ), especially in those with complications. In the multivariate analysis, an association was established between high $\mathrm{HbAlc}$ values and preeclampsia [(OR $6.48(2.48-16.93) \mathrm{p}<0.001]$. Conclusion: This study established that $46.5 \%$ of non-diabetic pregnant women with preeclampsia have high $\mathrm{HbAlc}$ values, which moreover are associated with preeclampsia and its complications. Systematic screening is essential for detecting preeclampsia or diabetes or both.

\section{Keywords}

HbA1c, Preeclampsia, Prognosis, Congo

\section{Introduction}

A disturbed glucose metabolism is quite common during pregnancy. It is linked to the diabetogenic potential of pregnancy and increase in the second half of gestation [1]-[6]. It may cause many complications including fetal malformations, prematurity, fetal death in utero, fetal macrosomia, preeclampsia and so on. In a large epidemiological study of 25,000 pregnant women, the risk of maternal and neonatal complications has been shown to increase linearly with maternal blood glycaemia [7] [8] [9] [10]. Furthermore, the International Diabetes Federation estimated the overall prevalence of hyperglycaemia during pregnancy at $16.9 \%$, which more than justifies systematic screening [11] [12]. Different strategies can highlight these glycemic disorders, including the determination of glycated hemoglobin (HbA1c) [13] [14] [15]. Many studies revealed that the increase in the level of HbAlc during pregnancy is closely associated with the unfavorable results and that its dosage is significant importance in the monitoring of complications of pregnancy, particularly that of preeclampsia [16] [17] [18]. Preeclampsia is one of the major causes of maternal and perinatal morbidity and mortality in developing countries, and, it's responsible for nearly 50,000 deaths in women each year [19] [20]. It is characterized by the association of high blood pressure and proteinuria occurring from the 20th week of gestation [21] [22]. In sub-Saharan Africa, the prevalence of this hypertensive pregnancy disorder re- 
mains very high and variable, reaching up to almost $20 \%$ of cases [23]. Although the main cause of this condition remains even less well known, many studies agree on the role played by oxidative stress in the occurrence of this condition [24]-[28]. The results obtained from numerous studies note that the prevalence of the disease is quite high in pregnant women with hyperglycaemia [29] [30]. The oxidative stress generated at all stages of protein glycation and during the formation of $\mathrm{HbAlc}$ would be favorable for the occurrence of preeclampsia and its complications. In addition, some studies report an association between high levels of $\mathrm{HbAlc}$ and anti-angiogenic factors implicated in the occurrence of preeclampsia [31]. More recently, a very significant association has been established between elevated levels of protein glycation end products (AGE: Advanced glycation end-products) with preeclampsia [32] [33] [34].

Thus, the evaluation of $\mathrm{HbAlc}$ in pregnant women with pre-eclampsia is essential to detect the hyperglycaemia states that may be associated and to research the influence of this marker on the prognosis of the disease.

The present study aims to describe the profile of HbAlc in non-diabetic pregnant women and to establish the association between the values of this marker with maternal and fetal complications.

\section{Materials and Method}

This is a case-control study involving 71 preeclamptic women (cases) and 71 non-preeclamptic women (controls) matched for gestational age, between May and October 2019. The study population comprised black non-diabetic preeclamptic women from two hospitals (University Clinics and the Kinshasa General Reference Hospital), in the Democratic Republic of the Congo. The sampling of preeclamptic pregnant women was exhaustive. Controls were healthy pregnant women carrying pregnancies of the same type and of the same gestational age as the cases. Ultimately, 71 were preeclamptic and 71 healthy (controls).

Diabetics pregnant, women with sickle cell anemia, and those with pathologies characterized by polycythemia were excluded from this study. Gestational age was calculated from the date of the last menstrual period in pregnant women with a regular menstrual cycle and from an early ultrasound in those who did not know their last menstrual dates or who had a history of spaniomenorrhea. Preeclampsia has been defined according to the criteria of the National High Blood Pressure Education Program of United States, namely the occurrence in the second part of the pregnancy of arterial hypertension (SAP $\geq 140 \mathrm{mmHg}$ and $\mathrm{DAP} \geq 90 \mathrm{mmHg}$ ) associated with proteinuria (quantitative $\geq 300 \mathrm{mg} / 24 \mathrm{~h}$ or qualitative $>$ with a cross evaluated by the strip method) in a previously normotensive woman. Preeclampsia was considered moderate when SAP was $\geq 140$ $\mathrm{mmHg}$ but $<160 \mathrm{mmHg}$ and the DAP was $\geq 90 \mathrm{mmHg}$ but $<110 \mathrm{mmHg}$ and in the absence of signs of severity. It was severe when the SAP was $\geq 160 \mathrm{mmHg}$ and/or the DAP $\geq 110 \mathrm{mmHg}$ or also in front of a hypertension associated with the following signs of severity: epigastric pain, nausea, vomiting, headache in 
helmet, osteotendinous hyperreflexia, headache, dizziness, blurred vision, ringing in the ears, convulsions, signs of acute lung edema, oliguria $(<20 \mathrm{ml} / \mathrm{H})$, or in front of serum creatinine $>100 \mu \mathrm{mol} / \mathrm{L}$, of increase of liver transaminases $>3$ times the normal value, of thrombocytopenia $<100,000 / \mathrm{mm}^{3}$.

The controls were healthy pregnant women carrying pregnancies of the same gestational age as the preeclamptics.

The socio-demographic characteristics, the clinical data as well as the biological parameters were noted in all those pregnant women and included maternal age, medical history, obstetric history, gestational age, type of pregnancy, clinical form of preeclampsia, maternal and fetal complications.

Hyperglycemia and High glycated hemoglobin A1C were defined by value $\geq$ $92 \mathrm{md} / \mathrm{dl}$ and $\geq 5.6 \%$ respectively [7] [8] [9] [10] [35]. The ranges considered normal were for urea $10-42 \mathrm{mg} / \mathrm{dl}$; for creatinine 0.5 - $2 \mathrm{mg} / \mathrm{dl}$, for GOT 5 - 41 IU/L, and for GPT 0 - $38 \mathrm{IU} / \mathrm{L}$. The reference value of hematological parameters is those used in our country. The assays of biological parameters were carried out in the clinical biology laboratory of the General Reference Hospital of Kinshasa and concerned the levels of glycated hemoglobin HbAlc (\%), of the fasting glycemia $(\mathrm{mg} / \mathrm{dl})$, of the urea $(\mathrm{mg} / \mathrm{dl})$, creatinine $(\mathrm{mg} / \mathrm{dl})$, GOT (IU/l), GPT (IU/l), hemoglobin (g\%), hematocrit (\%), the red blood cell count (elements $\left./ 10^{6}\right)$, white blood cells count (elements $/ \mathrm{mm}^{3}$ ) and platelets (elements $/ 10^{3}$ ). The haematological analyzes for the determination of hemoglobin and hematocrit as well as for the counting of platelets and red blood cells were carried out using the Mindray BC 52 analyzer which uses the principle of colorimetry for the determination of hemoglobin, flow cytometry and impedance for red blood cell and platelet count. The determination of glycated hemoglobin (HbA1c) was carried out on whole blood by the turbidimetry technique of the TINIA type (turbidimetric inhibition immunoassay) using a COBAS C111 brand analyzer [36]. The fasting blood glycaemia test was carried out using the Cobas C111 analyzer. SICKLE SCAN [37] was applied to find sickle cell anemia among these women. Obstetric ultrasound and fetal monitoring (NST) were used to establish the fetal well-being score (Manning score) and to search for fetal complications such as fetal growth retardation, fetal distress and death in utero.

The determination of urea and that of creatinine were carried out by the enzymatic methods of urease and creatininase respectively. The GOT and GPT transaminases were assayed by the kinetic method. Obstetric ultrasound and fetal monitoring (NST) were used to establish the fetal well-being score (Manning score) and to search for fetal complications such as fetal growth retardation, fetal distress and death in utero.

To carry out this study, we received the approval of the ethical committees of the school of public health of the faculty of Medicine of the University of Kinshasa. Only those pregnant women who freely expressed their consent were selected for the study.

The variables of interest were socio-demographic characteristics, the clinical 
data as well as the biological parameters were noted in all those pregnant women and mainly maternal age, medical history, obstetric history, gestational age, type of pregnancy, clinical form of preeclampsia, maternal and fetal complications.

\section{Processing and Analysis of Statistical Data}

\section{Statistical Analyzes}

The statistics used to describe the variables were means \pm standard deviation for continuous quantitative variables with symmetric distribution. Qualitative variables have been described in terms of absolute (n) and/or relative frequency (\%). For the analyses, the comparison of the means was carried out using the Student's t-test. Pearson's Chi-square or Fisher's exact test, as appropriate, was applied to compare the proportions. The linear regression test was applied to check the correlation between HbAlc and glycaemia. The linear regression coefficient in simple analysis was calculated to assess the association between $\mathrm{HbAlc}$ and glycaemia. Logistic regression was used to identify the factors associated with elevated $\mathrm{HbA1c}$ levels. Only the variables significantly associated with high $\mathrm{HbA1c}$ levels in univariate analysis were tested in multivariate analysis. The adjusted Odds-ratios (aOR) and their 95\% confidence intervals (CI) were reported to estimate the association between the independent variables and the dependent variable. The value of $\mathrm{p}<0.05, \mathrm{p}$ was considered statistically significant.

\section{Results}

A total of 142 pregnant women took part in this study consisting of 71 preeclamptic women (cases) and 71 healthy pregnant women (controls).

The socio-demographic characteristics of all these women are shown in Table 1. No significant difference is noted when comparing the two groups according to age, marital status, type of marriage and place of residence.

Table 1. Distribution according to socio-demographic characteristics.

\begin{tabular}{ccccc}
\hline Variables & $\begin{array}{c}\text { All } \\
\mathbf{n}=\mathbf{1 4 2}\end{array}$ & $\begin{array}{c}\text { PE } \\
\mathbf{n}=\mathbf{7 1}\end{array}$ & $\begin{array}{c}\text { Controls } \\
\mathbf{n}=\mathbf{7 1}\end{array}$ & $\mathbf{P}$ \\
\hline Age (years) & $28.8 \pm 6.8$ & $28.2 \pm 6.8$ & $29.5 \pm 6.8$ & 0.559 \\
$\leq 20$ & $18(12.7)$ & $11(15.5)$ & $7(9.9)$ & \\
$21-34$ & $93(65.5)$ & $46(64.8)$ & $47(66.2)$ & \\
$\geq 35$ & $31(21.8)$ & $14(19.7)$ & $17(23.9)$ & 0.372 \\
Marital status & & & & \\
Maried & $132(93.0)$ & $65(91.5)$ & $67(94.4)$ & \\
Single & $10(7.0)$ & $6(8.5)$ & $4(5.6)$ & \\
Type of marriage & & & $66(98.5)$ & \\
Monogamy & $128(97.0)$ & $62(95.4)$ & $1(1.5)$ & \\
Polygamy & $4(3.1)$ & $3(4.6)$ & & \\
\hline
\end{tabular}

Data are expressed as mean \pm standard deviation or absolute and relative frequency in \% between brackets. 
It appears however from the results of Table 2 that primigestity, primiparity, as well as the history of preeclampsia are mainly found in pregnant women with preeclampsia compared to controls $(\mathrm{p}<0.05)$.

Table 3 gives the characteristics of pregnancy in the two groups. There is a perfect pairing of two study groups in terms of gestational age.

Table 4 shows the clinical data for pregnant women in the two groups. We also note in pre-eclamptic pregnant women the presence of certain serious clinical signs such as convulsions, coma, headache, dizziness, blurred vision not found in the controls.

As illustrated in Figure 1, severe preeclampsia was the most common clinical form in pregnant women compared to moderate preeclampsia (62\% vs. $38 \%, \mathrm{p}<$ $0.001)$.

It appears from the results in Table 5 that among the many complications observed in pregnant women with preeclampsia, eclampsia was the most common

Table 2. Medico-gyneco-obstetric antecedents.

\begin{tabular}{ccccc}
\hline Variables & $\begin{array}{c}\text { All } \\
\mathbf{n}=142\end{array}$ & $\begin{array}{c}\text { PE } \\
\mathbf{n}=71\end{array}$ & $\begin{array}{c}\text { Controls } \\
\mathbf{n}=71\end{array}$ & $\mathbf{P}$ \\
\hline Parity & $2.3 \pm 1.5$ & $2.2 \pm 1.7$ & $2.4 \pm 1.2$ & 0.005 \\
1 & $48(33.8)$ & $29(40.8)$ & $19(26.8)$ & \\
$2-3$ & $65(45.8)$ & $28(39.4)$ & $37(52.1)$ & \\
$\geq 4$ & $29(20.4)$ & $14(19.7)$ & $15(21.1)$ & \\
Gestity & $3.6 \pm 1.6$ & $3.5 \pm 1.7$ & $3.7 \pm 1.3$ & 0.035 \\
1 & $10(7.0)$ & $9(12.7)$ & $1(1.4)$ & \\
$2-3$ & $62(43.7)$ & $30(42.3)$ & $32(45.1)$ & \\
$\geq 4$ & $70(49.3)$ & $32(45.1)$ & $38(53.5)$ & \\
Preeclampsia & & & & \\
No & $122(85.9)$ & $57(80.3)$ & $65(91.5)$ & \\
Yes & $20(14.1)$ & $14(19.7)$ & $6(8.5)$ & \\
\hline
\end{tabular}

Data are expressed as mean \pm standard deviation or absolute and relative frequency in \% between brackets.

Table 3. Characteristic of pregnancy.

\begin{tabular}{|c|c|c|c|c|}
\hline Variables & $\begin{array}{c}\text { All } \\
\mathrm{n}=142\end{array}$ & $\begin{array}{c}\text { PE } \\
\mathrm{n}=71\end{array}$ & $\mathrm{n}=71$ & $\mathbf{P}$ \\
\hline Age of pregnancy & & & & 0.036 \\
\hline $\mathrm{T} 2$ & $18(12.7)$ & $5(7.0)$ & $13(18.3)$ & \\
\hline $\mathrm{T} 3$ & $124(87.3)$ & $66(93.0)$ & $58(81.7)$ & \\
\hline Type of pregnancy & & & & 0.060 \\
\hline Monofoetal & $138(97.2)$ & $67(94.4)$ & $71(100.0)$ & \\
\hline Twins & $4(2.8)$ & $4(5.6)$ & $0(0.0)$ & \\
\hline
\end{tabular}

Data are expressed as absolute and relative frequency in \% between brackets. 
Table 4. Patient complaints and parameters.

\begin{tabular}{ccccc}
\hline Variables & $\begin{array}{c}\text { All } \\
\mathbf{n}=\mathbf{1 4 2}\end{array}$ & $\begin{array}{c}\mathbf{P E} \\
\mathbf{n}=\mathbf{7 1}\end{array}$ & $\begin{array}{c}\text { Controls } \\
\mathbf{n}=\mathbf{7 1}\end{array}$ & $\mathbf{P}$ \\
\hline High bloodpresure & $71(50.0)$ & $71(100.0)$ & $0(0.0)$ & - \\
Proteinuria & $71(50.0)$ & $71(100.0)$ & $0(0.0)$ & - \\
Edema & $72(50.7)$ & $63(88.7)$ & $9(12.7)$ & $<0.001$ \\
Headaches & $52(36.6)$ & $52(73.2)$ & $0(0.0)$ & - \\
Dizziness & $31(21.8)$ & $31(43.7)$ & $0(0.0)$ & - \\
Blurred vision & $9(6.3)$ & $9(12.7)$ & $0(0.0)$ & - \\
Convulsion & $52(36.6)$ & $52(73.2)$ & $0(0.0)$ & - \\
SBP & $120.0 \pm 8.4$ & $191.6 \pm 25.8$ & $109.9 \pm 21.5$ & $<0.001$ \\
DBP & $76.5 \pm 8.4$ & $110.6 \pm 14.4$ & $72.6 \pm 9.2$ & $<0.001$ \\
\hline
\end{tabular}

Data are expressed as mean \pm standard deviation or absolute and relative frequency in \% between brackets.

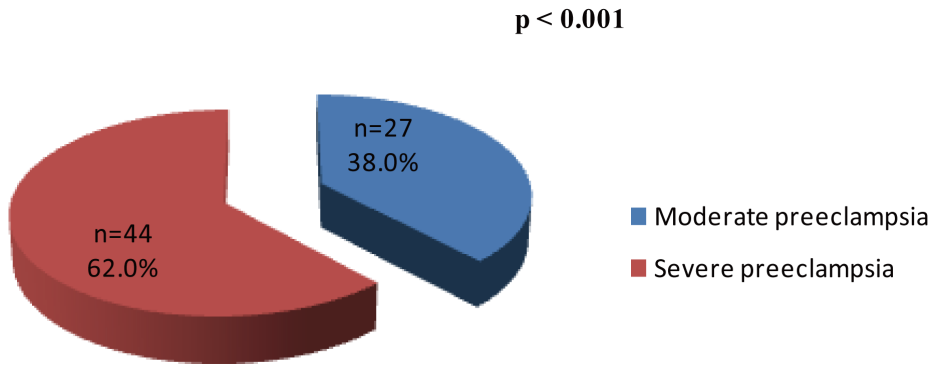

Figure 1. Type of preeclampsia.

Table 5. Complications of preeclampsia.

\begin{tabular}{|c|c|c|}
\hline Complications & Effective $(n=71)$ & $\%$ \\
\hline \multicolumn{3}{|l|}{ Maternal } \\
\hline Eclampsia & 52 & 73.2 \\
\hline HELLP Syndrome & 14 & 19.7 \\
\hline Acute renal failure & 5 & 7.0 \\
\hline Placental abruption & 5 & 7.0 \\
\hline Retinopathy & 2 & 2.8 \\
\hline Acute edema of the lung & 1 & 1.4 \\
\hline Pulmonary embolism & 1 & 1.4 \\
\hline Abortion & 1 & 1.4 \\
\hline \multicolumn{3}{|l|}{ Néonatal } \\
\hline Acute fetal pain & 44 & 62.0 \\
\hline Prematurity & 19 & 26.8 \\
\hline Intrauterine growth retardation & 7 & 9.9 \\
\hline Fetal death & 4 & 5.6 \\
\hline Oligohydramnios & 2 & 2.8 \\
\hline
\end{tabular}


complication in the mother, while on the fetal side, it was acute fetal distress and prematurity.

The blood parameter values are shown in Table 6. There are high levels of hepatic transaminases in preeclamptic pregnant women compared to controls (GOT: $48.3 \pm 5.9 \% \mathrm{IU} / \mathrm{L}$ vs $24.3 \pm 9.1 \% \mathrm{IU} / \mathrm{L}, \mathrm{p}=0.001$, GPT: $38.6 \pm 4.7 \% \mathrm{IU} / \mathrm{L}$ vs $13.8 \pm 6.9 \% \mathrm{IU} / \mathrm{L}, \mathrm{p}=0.000$ ). The same result could be found for the leukocyte count, whose values are higher in the preeclampticswomen than in the controls $\left(9766.2 \pm 432.1\right.$ elements $/ \mathrm{mm}^{3}$ vs $6424.0 \pm 179.6$ elements $\left./ \mathrm{mm}^{3}, \mathrm{p}<0.001\right)$. A significant decrease in platelet count is observed in pre-eclamptic pregnant women compared to controls $\left(167.8 \pm 74.3\right.$ elements $/ \mathrm{mm}^{3}$ vs $228.8 \pm 56.4$ elements $\left./ \mathrm{mm}^{3}, \mathrm{p}<0.001\right)$. The average fasting glycaemia is $88.4 \pm 28.8 \mathrm{mg} \%$ in the whole population. It is higher in preeclamptic pregnant women than in controls $(95.0 \pm 35.6 \mathrm{mg} / \mathrm{dl}$ vs $81.8 \pm 17.3 \mathrm{mg} / \mathrm{dl}, \mathrm{p}=0.006)$. Higher values of $\mathrm{HbAlc}$ are observed in pre-eclamptic pregnant women compared to controls $(5.7 \pm 1.3 \%$ vs $4.8 \pm 0.7 \%, \mathrm{p}<0.001)$.

It emerges from the analysis of Figure 2 below that the proportion of preeclamptic pregnant women with pathological values of fasting glycaemia $(\geq 92$ $\mathrm{mg} / \mathrm{dl}$ ) was comparable to that of the controls $34 \%$ vs $24 \%, \mathrm{p}=0.133$ ).

However, the proportion of pregnant women with pathological HbAlc values $(>5.6 \%)$ was significantly higher in the group of preeclamptic pregnant women compared to controls ( $46.5 \%$ vs $9.9 \%, \mathrm{p}<0.001$ ) (Figure 3 ).

A positive and significant linear correlation is noted between the HbAlc level

Table 6. Paraclinical examinations.

\begin{tabular}{ccccc}
\hline Variables & $\begin{array}{c}\text { All } \\
\mathbf{n}=142\end{array}$ & $\begin{array}{c}\text { PE } \\
\mathbf{n}=71\end{array}$ & $\begin{array}{c}\text { Controls } \\
\mathbf{n}=71\end{array}$ & $\mathbf{P}$ \\
\hline HbAlc (\%) & $5.3 \pm 1.1$ & $5.7 \pm 1.3$ & $4.8 \pm 0.7$ & $<0.001$ \\
Glycemia (mg/dl) & $88.4 \pm 28.8$ & $95.0 \pm 35.6$ & $81.8 \pm 17.3$ & 0.006 \\
Urea (mg/dl) & $27.3 \pm 11.3$ & $32.7 \pm 13.8$ & $22.0 \pm 9.3$ & 0.022 \\
Creatininemia (mg/dl) & $1.06 \pm 0.6$ & $1.3 \pm 0.8$ & $0.78 \pm 0.30$ & 0.010 \\
GOT (UI/l) & $36.4 \pm 7.2$ & $48.3 \pm 5.9$ & $24.3 \pm 9.1$ & 0.001 \\
GPT (UI/l) & $26.2 \pm 5.6$ & $38.6 \pm 4.7$ & $13.8 \pm 6.9$ & 0.000 \\
Hb (g\%) & $10.3 \pm 1.6$ & $10.0 \pm 1.7$ & $10.6 \pm 1.5$ & 0.030 \\
Hct (\%) & $30.5 \pm 4.6$ & $30.0 \pm 5.2$ & $30.9 \pm 3.9$ & 0.228 \\
RBC (élts/10 $)$ & $3.56 \pm 0.65$ & $3.62 \pm 0.7$ & $3.50 \pm 0.7$ & 0.253 \\
MCV (fl) & $82.2 \pm 7.1$ & $81.7 \pm 7.3$ & $81.1 \pm 0.8$ & 0.344 \\
MCHC & $33.3 \pm 1.7$ & $33.0 \pm 1.7$ & $33.8 \pm 1.5$ & 0.013 \\
MCH & $28.0 \pm 2.7$ & $28.0 \pm 2.9$ & $28.0 \pm 2.4$ & 0.988 \\
WBC (élts/mm $\left.{ }^{3}\right)$ & $8095.1 \pm 369.9$ & $9766.2 \pm 432.1$ & $6424.0 \pm 179.6$ & $<0.001$ \\
PLT (élts/10 $\left.{ }^{3}\right)$ & $198.3 \pm 72.5$ & $167.8 \pm 74.3$ & $228.8 \pm 56.4$ & $<0.001$ \\
\hline
\end{tabular}

Data are expressed as mean \pm standard deviation or absolute and relative frequency in \% between brackets. 


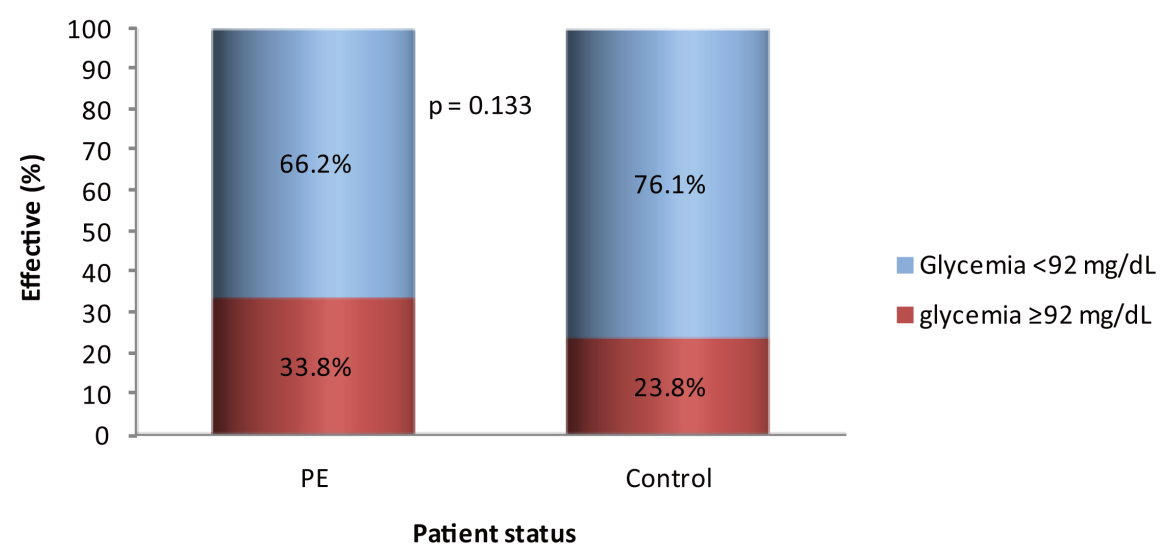

Figure 2. Comparisonglycemia between case and control.

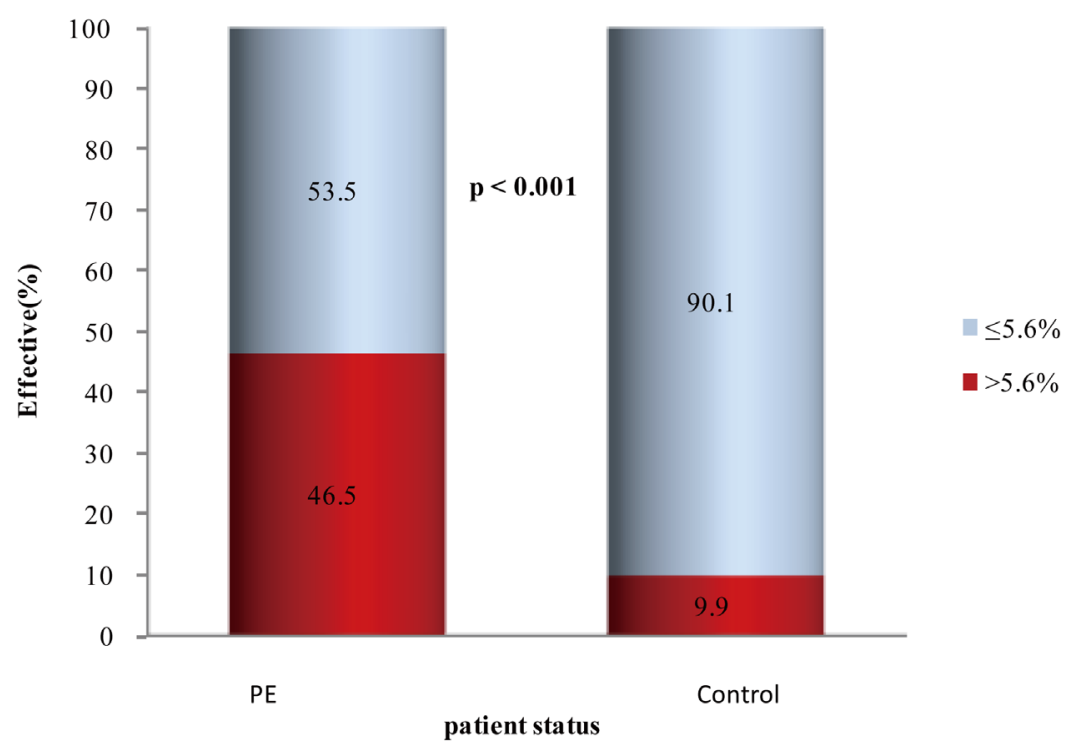

Figure 3. Frequency of pathological HbAlc values according to the control-case.

and the fasting glycaemia. This correlation is $88 \%(r=0.881)$ as shown in Figure 4 below.

Table 7 gives the clinical characteristics as a function of HbAlc values in preeclamptic pregnant women. It appears that a pathological values of $\mathrm{HbAlc}$ $(>5.6 \%)$ is significantly $(\mathrm{p}<0.00)$ more common in pregnant women with a history of preeclampsia or arterial hypertension, in those with complications such as eclampsia, eclamptic prodromes and prematurity; but also significantly in pregnant women with pregnancies complicated by acute fetal distress $(p=0.023)$ and in those carrying twin pregnancies $(\mathrm{p}=0.035)$.

Univariate analysis noted an association between high levels of HbAlc with preeclampsia (OR $7.94(3.20$ - 19.71) p < 0.001), with multigestity (OR 3.50 (1.89 - 7.70) $\mathrm{p}=0.020)$, and with carrying a twin pregnancy (OR $3.19(2.83-8.22) \mathrm{p}=$ $0.024)$. This association is also observed in multivariate analysis, between high levels of $\mathrm{HbA1c}$ with preeclampsia (OR 6.48 (2.48 - 16.93), and multigestity (OR $2.94(1.16-7.54) \mathrm{p}=0.007)$ as shown in Table 8. 


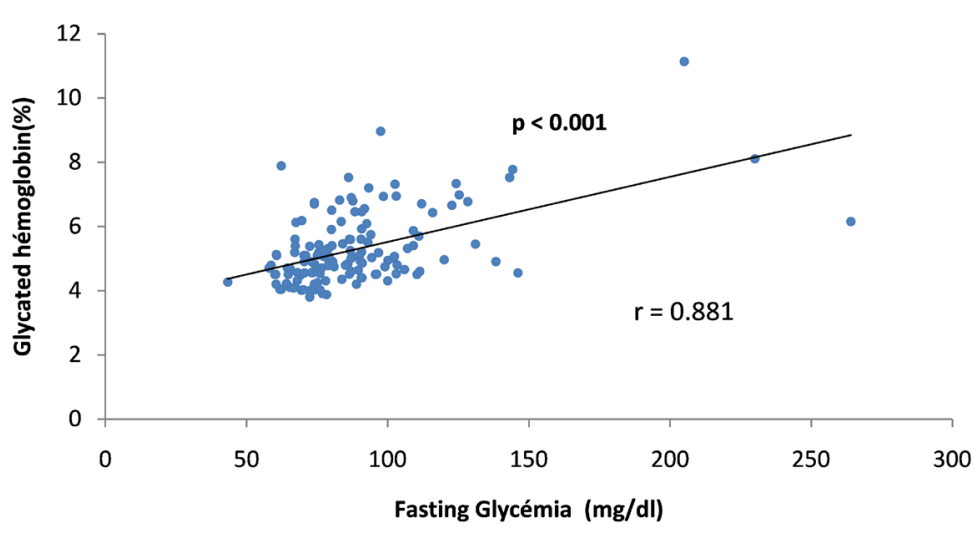

Figure 4. Simple linear correlation between fasting glycaemia and HbA1c.

Table 7. Clinical characteristics, maternal and fetal complications according to HbAlc values.

\begin{tabular}{|c|c|c|c|}
\hline Variables & $\begin{array}{c}\mathrm{HbA} 1 \mathrm{C} \leq 5.6 \% \\
\mathrm{n}=102\end{array}$ & $\begin{array}{c}\mathrm{HbA} 1 \mathrm{c}>5.6 \% \\
\mathrm{n}=40\end{array}$ & $\mathbf{P}$ \\
\hline Parity & & & 0.117 \\
\hline 1 & $32(31.4)$ & $16(40.0)$ & \\
\hline $2-3$ & $50(49.0)$ & $15(37.5)$ & \\
\hline$\geq 4$ & $20(19.6)$ & $9(22.5)$ & \\
\hline Gestity & & & 0.039 \\
\hline 1 & $4(3.9)$ & $6(15.0)$ & \\
\hline $2-3$ & $49(48.0)$ & $13(32.5)$ & \\
\hline$\geq 4$ & $49(48.0)$ & $21(52.5)$ & \\
\hline Antecedentof preeclampsia & $8(7.8)$ & $12(30.0)$ & 0.001 \\
\hline Headaches & $28(27.5)$ & $24(60.0)$ & $<0.001$ \\
\hline Dizziness & $14(13.7)$ & $17(42.5)$ & $<0.001$ \\
\hline Blurred vision & $5(4.9)$ & $4(10.0)$ & 0.224 \\
\hline Eclampsia & $24(23.5)$ & $28(70)$ & $<0,001$ \\
\hline Type of pregnancy & & & 0.035 \\
\hline Monofoetal & $101(99.0)$ & $37(92.5)$ & \\
\hline Twins & $1(1.0)$ & $3(7.5)$ & \\
\hline Rétinopathy & $1(1.0)$ & $1(3.0)$ & 0.717 \\
\hline Acute renal failure & $2(5.3)$ & $3(9.1)$ & 0.432 \\
\hline Placental abruption & $4(10.5)$ & $1(3.0)$ & 0.226 \\
\hline Prematurity & $5(13.2)$ & $14(42.4)$ & 0.006 \\
\hline Acute fetal pain & $19(50.0)$ & $25(75.8)$ & 0.023 \\
\hline Intra uterin growth retardation & $3(7.9)$ & $4(12.1)$ & 0.420 \\
\hline Fetal death in utero & $2(5.3)$ & $2(6.1)$ & 0.638 \\
\hline Liver injury & $5(13.2)$ & $9(27.3)$ & 0.117 \\
\hline
\end{tabular}

The data are expressed as absolute and relative frequency in \% between brackets. 
Table 8. Risk factors associated with HbAlc.

\begin{tabular}{|c|c|c|c|c|}
\hline \multirow{2}{*}{ Factors } & \multicolumn{2}{|c|}{ Univariate analysis } & \multicolumn{2}{|c|}{ Multivariate analysis } \\
\hline & $\mathrm{p}$ & OR (IC95) & $\mathrm{p}$ & ORa (IC95) \\
\hline \multicolumn{5}{|l|}{ Status } \\
\hline Controls & & 1 & & 1 \\
\hline $\mathrm{PE}$ & $<0.001$ & $7.94(3.20-19.71)$ & $<0.001$ & $6.48(2.48-16.93)$ \\
\hline \multicolumn{5}{|c|}{ Pregnancy type } \\
\hline Monofoetal & & 1 & & 1 \\
\hline Twins & 0.024 & $3.19(2.83-8.22)$ & 0.982 & $1.38(0.67-3.47)$ \\
\hline \multicolumn{5}{|l|}{ Gestity } \\
\hline 1 & & 1 & & 1 \\
\hline $2-3$ & 0.238 & $1.62(0.28-2.37)$ & 0.790 & $1.27(0.22-3.53)$ \\
\hline$\geq 4$ & 0.020 & $3.50(1.89-7.70)$ & 0.007 & $2.94(1.16-7.54)$ \\
\hline
\end{tabular}

\section{Discussion}

The objective of study was to establish an association between glycated hemoglobin $(\mathrm{HbA} 1 \mathrm{c})$ in the second and third trimester of pregnancy with the occurrence of preeclampsia and to investigate the influence of these glycated hemoglobin on the maternal and fetal prognosis. The reference value for the HbAlc used was 5.6\% [35]. It emerges from this study that in the absence of a proven diabetes mellitus context, preeclamptic women had higher $\mathrm{HbAlc}$ values compared to non-preeclampsia pregnant women. Pathological values of HbA1c $(>5.6 \%)$ are very significantly associated with preeclampsia and its complications. These results thus obtained underline the importance of regular glycemic controls to prevent these complications.

\subsection{Glucose Metabolism and Preeclampsia}

Preeclampsia remains one of the major causes of maternal and perinatal morbidity and mortality in developing countries where it kills nearly 50,000 women each year [20]. Although its main cause is largely unknown, numerous studies agree on the role played by oxidative stress [24]-[28]. Epidemiological studies show that hyperglycemic disorders occurring during pregnancy are a risk factor for the development of preeclampsia even outside of proven diabetes mellitus [29] [30]. These hyperglycemic disorders linked to the diabetogenic potential of pregnancy are the consequence of the anti-insulinogenic and lipolytic activity of the somatotropic chorionic hormone, prolactin, cortisol and glucagon whose concentrations increase in the second half of gestation [1]-[6]. In 2013, the International Diabetes Federation estimated the overall prevalence of hyperglycemia during pregnancy at $16.9 \%$ [12]. To date, several strategies have been used to detect these disorders, including oral provoked hyperglycemia test, fasting glycemia, as well as the determination of glycated hemoglobin HbAlc [38] [39]. 


\subsection{Glycemia and Glycated Hemoglobin Profile in Healthy and in Non-Diabetic Preeclamptic Women}

In this study, we used fasting glycemia and HbAlc determination. Although the oral hyperglycemia test remains one of the most widely used dynamic tests for the detection of carbohydrate intolerance, the difficulties associated with the supply of anhydrous glucose, its conservation and its cost limited the realization of this test during the present study. Fasting glycemia was measured by the hexokinase method which is a reference method [40]. The threshold value used is that proposed by ADA and adopted by WHO, $92 \mathrm{mg} / \mathrm{dl}$ [41]. The results obtained from the HAPO study (Hyperglycaemia and Adverse Pregnancy Outcomes) and those of other studies have shown that this value is the threshold at which maternal glycemia levels are frequently associated with unfavorable pregnancy outcomes [7] [42] [43]. The determination of glycated hemoglobin was carried out by the immunoturbidimetry technique using a COBAS C111 brand analyzer [36] [44]. The choice of the HbAlc dosage is justified by the fact that it reflects the state of glycemia during the 2 to 3 months preceding the measurement [45], its dosage is reproducible and its level is not influenced by the time of blood collection or by fasting status or by any hypo or hyperglycemic treatment [46]. In addition, the oxidative stress generated during the formation of $\mathrm{HbAlc}$ would be favorable for the occurrence of preeclampsia and its complications [47]-[51]. In order to avoid errors of interpretation linked to the shortening of the duration of red blood cells, we excluded from this study the cases of sickle cell anemia, the hemoglobinopathy most encountered in our population [52] [53]. The results of the study by Arlène et al. [54] as well as those of many authors indicate that $\mathrm{HbAlc}$ is not a reliable indicator in the search for glycemic disorders in subjects suffering from sickle cell anemia. Regarding the reference value of $\mathrm{HbAlc}$ used in the present study, although no consensus was found on the reference ranges of $\mathrm{HbAlc}$ in healthy pregnant women, the results published by numerous authors indicate that healthy pregnant women have lower $\mathrm{HbAlc}$ concentrations than non-pregnant women. O'Kane et al. [55] have suggested $\mathrm{HbA1C}$ levels of $5.1 \%, 4.9 \%$ and $5.0 \%$ in the first, second and third trimester, respectively, in healthy pregnant women. Nielsen et al. [56] found reference ranges between 4.5 and $5.7 \%$ in the first trimester and between 4.4 and $5.6 \%$ in the second and third trimester. The results of the study by O'connor et al. [57] showed that the reference values of $\mathrm{HbAlc}$ in Caucasian pregnant women were between 4.3 and $5.4 \%$ in the first trimester, between 4.4 and 5.4\% in the second trimester and between 4.7 and $5.7 \%$ in the third trimester. In their study, Versantvoort et al. [58] found $\mathrm{HbAlc}$ values in the range of 5.4, 5.5 and $5.8 \%$ in healthy pregnant women. These different results obtained in white women are sometimes misinterpreted.

In women of other races given the variability in $\mathrm{HbAlc}$ values related to race. We do not have any studies on glycated hemoglobin in pregnant black women. In a large study carried out in Mexico, Sánchez-González et al. [35] determined 
the HbAlc values of healthy pregnant women in the three trimesters of pregnancy. The calculated reference values were 5.6, 5.5 and 5.7\%, respectively in the first, second and third trimester, with an average of $5.6 \%$. We used the average of HbAlc found by Sánchez-González et al., who studied a large multiracial and multiethnic population.

We noted in the present study that the preeclamptic pregnant women had higher fasting blood glucose values compared to the controls $(95.0 \pm 35.6 \mathrm{mg} / \mathrm{dl}$ vs $81.8 \pm 17.3 \mathrm{mg} / \mathrm{dl}, \mathrm{p}=0.006)$. The proportions of pregnant women with pathological fasting glycemia values $(>92 \mathrm{mg} \%)$ were however comparable in the two study groups ( $33.8 \%$ vs. $23.9 \%, \mathrm{p}=0.133$ ).

Higher HbA1c values were observed in preeclamptic pregnant women compared to controls $(5.7 \pm 1.3 \%$ vs $4.8 \pm 0.7 \%, \mathrm{p}<0.001)$. These higher values of $\mathrm{HbAl} \mathrm{c}$ in preeclamptic pregnant women were found both in the second trimester $(5.7 \pm 1.3 \%$ vs $4.7 \pm 0.6 \%)$ and in the third trimester of pregnancy $(6.6 \pm 0.7 \%$ vs $4.8 \pm 0.8 \%)$. The proportion of pregnant women with pathological HbAlc values $(>5.6 \%)$ was higher in the group of preeclamptic pregnant women compared to controls ( $46.5 \%$ vs $9.9 \%, \mathrm{p}<0.001)$. In the multivariate analysis, an association was established between high $\mathrm{HbAlc}$ values and preeclampsia [(OR $6.48(2.48-16.93) \mathrm{p}<0.001]$.

\subsection{Glycated Hemoglobin and Preeclampsia}

It appears in the results obtained from the HAPO study and those of other studies than during pregnancy, the risk of maternal and neonatal complications increases linearly with maternal glycemia [7] [42] [43]. Several studies have established an association between the states of maternal hyperglycemia and the occurrence of preeclampsia and its complications [59] [60] [61]. However, the mechanism underlying this association remains less well known. Barden et al. [62] note in their study that insulin resistance is the essential factor in this association. In a large study aimed at identifying the determinants of the association between diabetes mellitus and preeclampsia, Gutaj et al. [63] rather note a very significant positive association between high values of $\mathrm{HbAlc}$ in the three trimesters of pregnancy with preeclampsia and its complications. The association between $\mathrm{HbAlc}$ levels and adverse pregnancy outcomes remains a large area to explore. Most of the data reported comes from first trimester HbAlc measurements in women with preexisting diabetes [16] [18]. It appears from the numerous studies carried out on pregnant diabetics that high HbAlc values are directly associated with unfavorable pregnancy outcomes and particularly with the occurrence of preeclampsia [64] [65] [66] [67]. Nielsen et al. [65] [66], Damm et al. [68], Tennant et al. [69] note in their studies high levels of HbAlc in pregnant diabetics with preeclampsia compared to non-preclamptics. In the HAPO study, the high levels of HbAlc measured in the second trimester of pregnancy in non-diabetic pregnant women were positively associated with a high prevalence of cesareans, preeclampsia and prematurity [70]. The results obtained from the 
study by Capula et al. [71] showed that, in pregnant women suffering from carbohydrate intolerance during the second trimester, even if the glycemic values are below the threshold of proven diabetes, the high rates of $\mathrm{HbAlc}$ remained strong predictors of adverse obstetric outcomes. In particular, an $\mathrm{HbAlc}$ value greater than $5.3 \%$ is associated with a 2 times higher risk of occurrence of preeclampsia and neonatal morbidity. In a recent study carried out in New Zealand on 16,122 healthy pregnant women, Hughes et al. [72] showed that an HbA1c level $\geq 5.9 \%$ at the start of pregnancy was a clinically relevant marker of the occurrence of preeclampsia, shoulder dystocia and perinatal death. Our results corroborate those of the HAPO study as well as those obtained by Capula et al., then recently by Hugues et al. who note an association between high levels of $\mathrm{HbAlc}$ and the occurrence of preeclampsia in pregnant women with unknown diabetes.

It appears from the results of Nielsen et al. [66], that in pregnant women, each increase in the value of $\mathrm{HbAlc}$ by $1 \%$ above the normal threshold increases the risk of poor perinatal results by $5.5 \%$. This risk is $79 \%$ when the $\mathrm{HbAlc}$ level is greater than 10.3\%. Mané et al. [16] note in their study that in pregnant women without diabetes, an $\mathrm{HbA} 1 \mathrm{c}$ level between $5.9 \%$ and $6.4 \%$ multiplies by 3 the risk of occurrence of preeclampsia and its complications. The results obtained from the study by Cavero-Redondo et al. [73] show that HbAlc is a very reliable indicator of the risk of cardiovascular mortality in diabetics and non-diabetics. In this regard, The National Institute for Health and Clinical Excellence (NICE) [74] [75] recommended an HbA1c level $<6.1 \%$ before considering conception in a known diabetic pregnant woman; and this rate must be even lower for an non-diabetic pregnant woman in order to avoid the occurrence of serious obstetric complications, particularly the occurrence of preeclampsia and its complications. Indeed, the oxidative stress generated at all stages of protein glycation and during the formation of $\mathrm{HbAlc}$ is favorable to the occurrence of preeclampsia and its complications, making this parameter a true marker of oxidative stress and therefore one of the parameters for assessing the severity and the maternal and fetal prognosis during preeclampsia [47]-[51]. Results obtained from certain studies have shown an association between high levels of HbAlc and anti-angiogenic factors, such as soluble endogline (Seng), implicated in the occurrence of preeclampsia and its complications [31] [76]. In addition, high levels of HbA1c have been shown to favor aggregability and platelet activation, which leads to the release of Thromboxan A2, a potent vasoconstrictor implicated in the pathophysiology of preeclampsia [77]. More recently, studies have demonstrated the role played by HbAlc in the pathophysiology of preeclampsia through the end products of glycation (AGE Advanced glycation end-products). AGEs are a diverse group of reactive molecules that are formed endogenously from intermediate and irreversible glycation products of which HbA1c is a part. These molecules are associated with high concentrations of free oxygen radicals and are responsible for a strong inflammatory reaction, which is thought to be the basis of endo- 
thelial dysfunction [78] [79] [80].

The results of numerous studies [81] [82] have shown very high concentrations of AGEs in preeclamptic pregnant women.

\subsection{Glycated Hemoglobin and Risk Factors of Preeclampsia in Non-Diabetic Women}

We noted during this study that primigestity, primiparity and a history of preeclampsia were risk factors for the onset of the disease. Our results corroborate those published by other authors. Merviel et al. [83] note in their study that primigestity, primiparity, primipaternity as well as personal history of preeclampsia are risk factors for the occurrence of preeclampsia. Similar results are published by English et al. [84] as well as by Cissé et al. [85]. In the study by Gutaj et al. [63], it was noted that the history of nulliparity associated with the high level of HbA1c between 12 - 24 weeks of pregnancy constituted a major risk factor for the occurrence of preeclampsia.

The same is true for the history of primiparity or hypertension associated with high levels of $\mathrm{HbA} 1 \mathrm{c}$ in the three trimesters of pregnancy which constitutes a major risk factor for the occurrence of preeclampsia. It thus emerges from our study that primigestity, primiparity, history of preeclampsia or hypertension are risk factors for the occurrence of preeclampsia. This risk is increased and multiplied by 7 in the presence of high levels of HbA1C measured in the second and third trimester in an unknown diabetic pregnant. In the study by Mohamed et al. [86], it was noted that multigestity was one of the risk factors for the occurrence of preeclampsia. We noted in this study an association between high levels of HbA1c and preeclampsia (OR $6.48(2.48-16.93) \mathrm{p}<0.001)$, and multigestity (OR $2.94(1.16-7.54) \mathrm{p}=0.007)$. Although multigestity was not found among the maternal risk factors for preeclampsia in the present study, its association with elevated rates of $\mathrm{HbAlc}$ makes this parameter another risk factor for the onset of the disease.

Probably the diabetogenic potential of recurring pregnancies would be the mechanism underlying the association between multigestity and high levels of HbAlc. Twin pregnancy is considered by many authors [87] [88] as one of the risk factors for the occurrence of preeclampsia by more complex mechanisms. The importance of oxidative stress would probably be one of the fundamental mechanisms for the occurrence of preeclampsia in this condition. In this study, we noted a predominance of twin pregnancies among preeclamptic pregnant women. In univariate analysis, we established an association between twin pregnancy and the high values of HbAlc (OR $3.19(2.83-8.22), \mathrm{p}=0.024)$ and between high values of HbAlc and preeclampsia (OR 7.94 (3.20 - 19.71) p < 0.001). Simmons et al. [89], Dwyer et al. [90] noted in their studies the greater diabetogenic potential associated with twin pregnancy due to the abundant secretion of the somatotropic chorionic hormone, compared to single pregnancy. This makes twin pregnancy a risk factor for the development of gestational diabetes and 
preeclampsia.

\subsection{Glycated Hemoglobin and Preeclampsia Prognosis}

We noted in this study that severe preeclampsia was the most common form, unlike moderate preeclampsia ( $62 \%$ vs $32 \%$ ). Our observation is similar to that of Cisse C.T et al. [85] who find in developing countries the predominance of severe forms of preeclampsia whose frequency can reach up to $88.7 \%$ of cases, according to studies. The results of our study show that eclampsia, acute fetal distress and prematurity were the most common obstetric complications. They were found very significantly in preeclamptic pregnant women with pathological HbAlc values $(>5.6 \%)$. It appears from the results obtained from the study by Ekbom et al. [91] that the risk of preterm delivery significantly increases with the elevation of HbA1c levels, making this parameter a true predictor of prematurity. Several mechanisms can be evoked to explain the occurrence of these complications in these pregnant women with pathological values of HbAlc, among which the importance of the oxidative stress generated during the formation of $\mathrm{HbAlc}$ and its impact on endothelial functioning, influence of anti-angiogenic factors associated with high levels of HbAlc but also the importance of the inflammatory reaction associated with the glycation process.

We noted in this study that preeclamptic pregnancies were characterized by high levels of HbA1c as well as higher values of leukocytes compared to controls ( $\mathrm{p}<0.001)$. Liu et al. [92], Wu et al. [93], and Sushma et al. [94] observed high concentrations of inflammation markers in subjects with elevated levels of HbA1c, making HbAlc a marker reliable inflammation [95]. Furthermore, the results of numerous studies show an association between inflammation and preeclampsia [96] [97] [98]. HELLP syndrome (Hemolysis, elevated liver enzymes and low platelet) is another severe complication found in severe forms of preeclampsia [99] [100].

It occurs as a result of endothelial damage associated with the obstruction of intrahepatic micro vessels by microthrombi [101]. It is characterized by hemolysis, elevated liver transaminases and thrombocytopenia. It was noted in the present study that compared to the controls, the preeclamptic pregnant women presented a moderate but very significant elevation of hepatic transaminase levels $($ GOT $48.3 \pm 5.9 \mathrm{IU} / \mathrm{L}$ vs $24.3 \pm 9.1 \mathrm{IU} / \mathrm{L}, \mathrm{p}=0.001$; GPT $38.6 \pm 4.7 \mathrm{IU} / \mathrm{L}$ vs $13.8 \pm 6.9 \mathrm{IU} / \mathrm{L}, \mathrm{p}=0.000)$ as well as a low platelet count $(167.8 \pm 74.3 .103$ elements vs $228.8 \pm 56.4 .103$ vs elements, $\mathrm{p}<0.001)$. Although this study did not establish a relationship between pathological values of $\mathrm{HbAlc}$ and the occurrence of this complication, it can be understood that the endothelial dysfunction caused by high levels of HbAlc and by Advanced glycation end-products would be one of the pathophysiological mechanisms. In the study by Asadifar et al. [77], it was shown that high levels of HbAlc also favored aggregability and the platelet activation which would be responsible for the formation of microthrombi and multi visceral attack which can lead HELLP syndrome. 
This study is the first to be carried out in Congolese pregnant women. Its weakness lies first, to the small sampling used and the failure to carry out the oral provoked hyperglycemia test in women with pathological values of HbA1c, which would contribute to determining the prevalence of diabetes mellitus, and secondly, the absence of data relating to neonatal parameters on which high levels of HbAlc could have an influence. This prompts us to recommend carrying out a study on a large sampling taking into account all these other aspects.

The strength of this study is to have established in non-diabetic pregnant women, a relationship between the high levels of HbAlc in the second and third trimester of pregnancy with the occurrence of preeclampsia and its complications, which allows to consider this parameter as a bio-marker of oxidative stress and of the appreciation for the maternal and fetal prognosis during preeclampsia. Our results corroborate those published by other authors, and underline the importance of glycemic control during the second and third trimester of pregnancy among the strategies for preventing preeclampsia and its complications.

\section{Conclusion}

We searched to determine the profile of glycated hemoglobin in non-diabetic preeclamptic pregnant women and know if elevated HbAlc levels were associated with maternal and fetal complications during this affection. It appears from the results obtained that $46.5 \%$ of those women have high levels of HbA1C. These high levels of HbAlc noted in the second and third trimester of pregnancy are very significantly associated with preeclampsia and are observed mainly in those with maternal or fetal complications. Thus, the integration of the HbAlc level of the second and third trimester among the other risk factors such as primiparity, primigestity, multigestity, and the history of hypertension could help to better assess the risk of preeclampsia and to assess the maternal and fetal prognosis during this condition. These results corroborate those published by other authors. They emphasize the importance of the systematic screening of hyperglycemic disorders during pregnancy. Some limitations of the study being noted, we recommend a study on a large sample in order to validate these results to make HbA1c a marker of risk of occurrence of preeclampsia and for appreciation of the maternal and fetal prognosis in our environment faced with the difficulties of assaying markers of oxidative stress.

\section{Acknowledgements}

The authors are grateful to the staff of the University Clinic of Kinshasa and General hospital of Kinshasa, DR Congo for their logistic support and they also thank the participants. This study was not supported by any specific grant. It was part of the memory for specialization in Clinical Biology of Doctor Guelord MUKIAPINI LUZOLO, who gratefully acknowledges the financial support received from the ALUMNI of the Faculty of Medicine of the KU Leuven (Belgium) for the realization of this study. 


\section{Conflicts of Interest}

The authors declare no conflicts of interest regarding the publication of this paper.

\section{References}

[1] Pratap, K. and Navneet, M. (2012) Hormones in Pregnancy. Nigerian Medical Journal, 53, 179-183. https://doi.org/10.4103/0300-1652.107549

[2] O’Sullivan, J.B., Gellis, S.S., Dandrow, R.V. and Tenney, B.O. (2003) The Potential Diabetic and Her Treatment in Pregnancy. Obstetrics \& Gynecology, 27, 683-689.

[3] Amit, D.S., Shivaleela, M.B., Dattareya, K. and Jayaprakash, M.D. (2014) Normal Pregnancy: A State of Insulin Resistance. Journal of Clinical Diagnostic Research, 8, $1-3$.

[4] Grigorakis, S.I., Alevizaki, M., Beis, C., Anastasiou, E., Alevizaki, C.C. and Souvatzoglou, A. (2000) Hormonal Parameters in Gestational Diabetes Mellitus during the Third Trimester: High Glucagon Levels. Gynecologic and Obstetric Investigation, 49, 106-109. https://doi.org/10.1159/000010225

[5] Riskin-Mashiah, S., Damti, A., Younes, G. and Auslender, R. (2010) First Trimester Fasting Hyperglycemia as a Predictor for the Development of Gestational Diabetes Mellitus. European Journal of Obstetrics \& Gynecology and Reproductive Biology, 152, 163-167. https://doi.org/10.1016/j.ejogrb.2010.05.036

[6] Seshiah, V., Balaji, B., Madhuri, B., Arunachalam, P. and Anil, K. (2009) Pregnancy and Diabetes Scenario around the World: India. International Journal of Gynecology \& Obstetrics, 104, 35-38. https://doi.org/10.1016/j.ijgo.2008.11.035

[7] The HAPO Study Cooperative Research Group (2008) Hyperglycemia and Pregnancy Adverse Outcomes. The New England Journal of Medicine, 358, 1991-2002.

[8] Song-Ying, S., Li-Fang, Z., Jian-Rong, H.E., Jin-Hua, L., Nian-Nian, C., Wan-Qing, X., Ming-Yang, Y., Hui-Min, X., Kin-Bong, H.L. and Xiu, Q. (2018) Association between Maternal Hyperglycemia and Composite Maternal-Birth Outcomes. Frontiers in Endocrinology, 9, 1-7.

[9] Juan, G., Aizhen, L., Xiaoling, S. and Ling, F.E. (2014) Association between Hyperglycemia in Middle and Late Pregnancy and Maternal-Fetal Outcomes: A Retrospective Study. BMC Pregnancy Childbirth, 14, 14-34. https://doi.org/10.1186/1471-2393-14-34

[10] Diane, F., Fairley, L., Santorelli, G., Tuffnell, D., Sheldon, T.A., Wright, J., Van Overveld, L. and Lawlor, D.A. (2015) Association between Hyperglycaemia and Adverse Perinatal Outcomes in South Asian and White British Women: Analysis of Data from the Born in Bradford Cohort. The Lancet Diabetes \& Endocrinology, 3 , 795-804. https://doi.org/10.1016/S2213-8587(15)00255-7

[11] Safiness, S.M., Haikael, D.M., Akwilina, W.M. and Pammla, P. (2019) Prevalence of Hyperglycemia in Pregnancy and Influence of Body Fat on Development of Hyperglycemia in Pregnancy among Pregnant Women in Urban Areas of Arusha Region, Tanzania. BMC Pregnancy and Childbirth, 19, 315-324. https://doi.org/10.1186/s12884-019-2463-8

[12] Diane, F. (2016) Hyperglycemia in Pregnancy: Prevalence, Impact, and Management Challenges. International Journal of Women's Health, 8, 519-527. https://doi.org/10.2147/IJWH.S102117

[13] American Diabetes Association (ADA), European Association for the Study of Di- 
abetes (EASD), International Federation of Clinical Chemistry and Laboratory Medecine (IFCC) and International Diabetes Federation (IFD) (2007) Consensus Statement on the Worldwide Standardization of Hemoglobin A1c Measurement. Diabetes Care, 30, 141.

[14] American Diabetes Association (2019) Classification and Diagnosis of Diabetes: Standards of Medical Care in Diabetes-2019. Diabetes Care, 42, 13-28. https://doi.org/10.2337/dc19-S002

[15] Mehany, M.A., Mohamed, A.O., Alaa, M.A. and Mohamed, A.E. (2019) Role of Glycosylated Hemoglobin in Prediction of Birth Weight and Amniotic Volume in Gestational Diabetes. Menoufia Medical Journal, 31, 1258-1264.

[16] Mañé, L., Flores-Le Roux, J.A., Benaiges, D., Rodríguez, M., Marcelo, I., Chillarón, J.J., Pedro-Botet, J., Llauradó, G., Gortazar, L., Carreras, R. and Payà, A. (2019) Role of First-Trimester HbAlc as a Predictor of Adverse Obstetric Outcomes in a Multiethnic Cohort. The Journal of Clinical Endocrinology \& Metabolism, 102, 390-397.

[17] Shobha, P., Sherly, M. and Joison, A. (2016) Glycosylated Hemoglobin Values in Nondiabetic Pregnant Women in the Third Trimester and Adverse Fetal Outcomes: An Observational Study. Journal of Family Medicine and Primary Care, 5, 646-651. https://doi.org/10.4103/2249-4863.197313

[18] Cavero-Redondoa, I., Martínez-Vizcaínoab, V., Soriano-Canoa, A., Martínez-Hortelanoa, J.A., Sanabria-Martínezac, G. and Álvarez-Buenoa, C. (2018) GlycatedhaemoglobinA1c as a Predictor of Preeclampsia in Type 1 Diabetic Pregnant Women: A Systematic Review and Meta-Analysis. Pregnancy Hypertension, 14, 49-54. https://doi.org/10.1016/j.preghy.2018.04.004

[19] Duley, L. (2009) The Global Impact of Pre-Eclampsia and Eclampsia. Seminars in Perinatology, 33,130-137. https://doi.org/10.1053/j.semperi.2009.02.010

[20] Duley, L. (1992) Maternal Mortality Associated with Hypertensive Disorders of Pregnancy in Africa, Asia, Latin America and the Caribbean. British Journal of $O b$ stetrics and Gynaecology, 99, 547-553. https://doi.org/10.1111/j.1471-0528.1992.tb13818.x

[21] National High Blood Pressure Education Program Working Group (1990) Report on High Blood Pressure in Pregnancy. American Journal of Obstetrics \& Gynecology, 163, 1691-1712. https://doi.org/10.1016/0002-9378(90)90653-O

[22] Bethesda, M. (2000) Report of the National High Blood Pressure Education Program Working Group on High Blood Pressure in Pregnancy. American Journal of Obstetrics \& Gynecology, 183, 1-22. https://doi.org/10.1067/mob.2000.107928

[23] Kayode, O.O. and Olusimbo, K. (2011) Public Health Perspectives of Preeclampsia in Developing Countries: Implication for Health System Strengthening. Journal of Pregnancy, 2011, 1-6. https://doi.org/10.1155/2011/481095

[24] Aouache, R., Biquard, L., Vaiman, D. and Miralles, F. (2018) Oxidative Stress in Preeclampsia and Placental Diseases. International Journal of Molecular Sciences, 19, 1-65. https://doi.org/10.3390/ijms19051496

[25] Raijmakers, M.T., Dechend, R. and Poston, L. (2004) Oxidative Stress and Preeclampsia: Rationale for Antioxidant Clinical Trials. Hypertension, 44, 374-380. https://doi.org/10.1161/01.HYP.0000141085.98320.01

[26] Michael, G.E. (2016) Oxidative Stress and the Evolutionary Origins of Preeclampsia. Journal of Reproductive Immunology, 114, 75-80. https://doi.org/10.1016/j.jri.2016.02.003

[27] Hugo, M.Z., Alejandro, P.F., Araceli, A.C. and Victoria, D.G. (2013) Oxidative Stress in Preeclampsia, More than Enzymes. Revista Latino americana de Hiperten- 
sión, 8, 25-28.

[28] Theresa, O.S., Maria, L., Xinhua, C., Melissa, S. and Peter, S. (2005) Oxidative Stress, Diet, and the Etiology of Preeclampsia. The American Journal of Clinical Nutrition, 81, 1390-1396. https://doi.org/10.1093/ajcn/81.6.1390

[29] Sibai, B.M., Caritis, S., Hauth, J., Lindheimer, M., Van, D., Orsten, J.P., MacPherson, C., Klebanoff, M., Landon, M., Miodovnik, M., Paul, R., Meis, P., Dombrowski, M., Thurnau, G., Roberts, J. and McNellis, D. (2000) Risks of Preeclampsia and Adverse Neonatal Outcomes among Women with Pregestational Diabetes Mellitus. National Institute of Child Health and Human Development Network of Maternal-Fetal Medicine Units. American Journal of Obstetrics \& Gynecology, 182, 364-369. https://doi.org/10.1016/S0002-9378(00)70225-0

[30] Shamsi, U., Hatcher, J., Shamsi, A., Zuberi, N., Qadri, Z. and Saleem, S.A. (2010) Multicentre Matched Case Control Study of Risk Factors for Preeclampsia in Healthy Women in Pakistan. BMC Women's Health, 10, 1-17. https://doi.org/10.1186/1472-6874-10-14

[31] Cohen, A.L., Wenger, J.B., James-Todd, I., Lamparello, B.M., Halprin, E., Serdy, S., Fan, S., Horowitz, G.L., Lim, H.K., Rana, S., Tamara, C.T., Wyckoff, J.A., Thadhani, R., Karumanchi, S.A. and Brown, F.M. (2014) The Association of Circulating Angiogenic Factors and HbA1c with the Risk of Preeclampsia in Women with Preexisting Diabetes. Hypertension in Pregnancy, 33, 81-92.

https://doi.org/10.3109/10641955.2013.837175

[32] Cooke, C.L., Brockelsby, J.C., Baker, P.N. and Davidge, S.T. (2003) The Receptor for Advanced Glycation End Products (RAGE) Is Elevated in Women with Preeclampsia. Hypertension in Pregnancy, 22, 173-184. https://doi.org/10.1081/PRG-120021068

[33] Na, X., Weiping, C., Yan, Z., Jing, L., Ning, Z. and Yuanhuan, Y. (2015) Correlation of the Expressions of Advanced Glycation End Products and Its Receptor in Serum and Placenta with the Pathogenesis of Preeclampsia. Chinese Journal of Obstetrics and Gynecology, 50, 493-499.

[34] Oliver, E.A., Buhimschi, C.S., Dulay, A.T., Baumbusch, M.A., Abdel-Razeq, S.S., Lee, S.Y., Zhao, G., Jing, S., Pettker, C.M. and Buhimschi, I.A. (2011) Activation of the Receptor for Advanced Glycation End Products System in Women with Severe Preeclampsia. The Journal of Clinical Endocrinology \& Metabolism, 96, 689-698. https://doi.org/10.1210/jc.2010-1418

[35] Sánchez-González, C.M., Castillo-Mora, A., Alvarado-Maldonado, I.N., OrtegaGonzález, C., Martínez-Cruz, N., Arce-Sánchez, L., Ramos-Valencia, M., MolinaHernández, A., Estrada-Gutierrez, G., Espino, S.Y.S., Recio-López, Y., Hernández-Sánchez, R. and Reyes-Muñoz, E. (2018) Reference Intervals for Hemoglobin A1c (HbA1c) in Healthy Mexican Pregnant Women: A Cross-Sectional Study. BMC Pregnancy Childbirth, 18, 1-17. https://doi.org/10.1186/s12884-018-2057-x

[36] Metus, P., Ruzzante, N., Bonvicini, P., Meneghetti, M., Zaninotto, M. and Plebani, M. (1999) Immunoturbidimetric Assay of Glycated Hemoglobin. Journal of Clinical Laboratory Analysis, 13, 5-8. https://doi.org/10.1002/(SICI)1098-2825(1999)13:1<5::AID-JCLA2>3.0.CO;2-S

[37] Segbena, A.Y., Guindo, A., Buono, R., Kueviakoe, I., Diallo, D.A., Guernec, G., Yerima, M., Guindo, P., Lauressergues, E., Mondeilh, A., Picot, V. and Leroy, V. (2018) Diagsnostic Accuracy in Field Conditions of the Sickle SCAN ${ }^{\circledR}$ Rapid Test for Sickle Cell Disease among Children and Adults in Two West African Settings: The DREPATEST Study. BMC Hematology, 18, 26. 
https://doi.org/10.1186/s12878-018-0120-5

[38] Sevket, O., Sevket, A., Ozel, A., Dansuk, R. and Kelekci, S. (2014) The Use of HbA1c as an Aid in the Diagnosis of Gestational Diabetes Mellitus. Journal of Obstetrics and Gynaecology, 34, 690-692. https://doi.org/10.3109/01443615.2014.925855

[39] Schaible, B., Calhoum, B.C., Bush, S., Ramser, B., Seybold, D.J., Broce, M., Fending, P., White, A., Williams, D.L. and Bracero, L.A. (2018) Hemoglobin A1c as a Screening Strategy for Gestational Diabetes. Medical and Dental Research, 1, 1-4. https://doi.org/10.15761/MDR.1000103

[40] Lunnsay, M.D., Eckhart, J.B., Charl Janse, V.R. and Shane, A.N. (2019) The Impact of Differences in Plasma Glucose between Glucose Oxidase and Hexokinase Methods on Estimated Gestational Diabetes Mellitus Prevalence. Scientific Report, 9, 7238. https://doi.org/10.1038/s41598-019-43665-x

[41] International Association of Diabetes and Pregnancy Study Groups (2010) Recommendations on the Diagnosis and Classification of Hyperglycemia in Pregnancy. Diabetes Care, 33, 676-682. https://doi.org/10.2337/dc09-1848

[42] Metzger, B.E., Lowe, L.P., Dyer, A.R., Trimble, E.R., Chaovarindr, U., Coustan, D.R., Hadden, D.R., McCance, D.R., Hod, M., McIntyre, H.D., Oats, J.J.N., Persson, B., Rogers, M.S., Sacks, D.A. and HAPO Study Cooperative Research Group (2008) Hyperglycemia and Adverse Pregnancy Outcomes. The New England Journal of Medicine, 358, 1991-2002. https://doi.org/10.1056/NEJMoa0707943

[43] Moses, R.G. and Calvert, D. (1995) Pregnancy Outcomes in Women without Gestational Diabetes Mellitus Related to the Maternal Glucose Level. Is There a Continuum of Risk? Diabetes Care, 18, 1527-1533. https://doi.org/10.2337/diacare.18.12.1527

[44] Lyon, A.W., Schaan, B., Laxdal, V.A. and Massey, K.L. (1995) Evaluation of an Immunoturbidimetric Assay for Hemoglobin A1c. Clinical Biochemistry, 28, 97-100. https://doi.org/10.1016/0009-9120(94)00061-Y

[45] Roszyk, L., Faye, B., Sapin, V., Somda, F. and Tauveron, I. (2007) Glycated Haemoglobin (HbA1c): Today and Tomorrow. Annales d Endocrinologie, 68, 357-365. https://doi.org/10.1016/j.ando.2007.06.004

[46] Gabbe, S.G. and Graves, C.R. (2003) Management of Diabetes Mellitus Complicating Pregnancy. Obstetrics \& Gynecology, 102, 857-868. https://doi.org/10.1016/j.obstetgynecol.2003.07.001

[47] D’Souza, J.M.P., D’Souza, R.P., Vijin, V.F., Shetty, A., Arunachalam, C., Pai, V.R., Shetty, R. and Faarisa, A. (2016) High Predictive Ability of Glycated Hemoglobin on Comparison with Oxidative Stress Markers in Assessment of Chronic Vascular Complications in Type 2 Diabetes Mellitus. Scandinavian Journal of Clinical and Laboratory Investigation, 76, 51-57. https://doi.org/10.3109/00365513.2015.1092048

[48] Dalan, R., Goh, L.L., Tang, X., Chew, D.E.K. and Boehm, B. (2018) Total Oxidative Index Is Associated with Glycated Hemoglobin, Low-Grade Inflammation, and Non-HDL Cholesterol in Type 2 Diabetes. Diabetes, 67, 419. https://doi.org/10.2337/db18-419-P

[49] Elgadir, A.A., Ahmed, L.O. and Babker, A. (2018) Correlation Of Oxidative Stress Markers Malondialdehyde (Mda), Antioxidant Vitamins A, E, And C With Glycated Hemoglobin (Hbalc) Levels in Type 2 Diabetes Mellitus. Asian Journal of Pharmaceutical and Clinical Research, 11, 281-283.

https://doi.org/10.22159/ajpcr.2018.v11i5.24548

[50] Varashree, B.S. and Gopalakrishna, B.P. (2011) Correlation of Lipid Peroxidation with Glycated Haemoglobin Levels in Diabetes Mellitus. Journal of Health \& Allied 
Sciences, 10, 1-4.

[51] Ivan, C.R., Barbara, P., Cella, A.B., Fernando, A.R. and Vicente, M.V. (2017) Glycated Haemoglobin Alc as a Risk Factor of Cardiovascular Outcomes and All-Cause Mortality in Diabetic and Nondiabetic Populations: A Systematic Review and Meta-Analysis. BMJ Open, 7, 1-25. https://doi.org/10.1136/bmjopen-2017-015949

[52] Agasa, B., Bosunga, K., Opara, A., Tshilumba, K., Dupont, E., Vertongen, F., Cotton, F. and Gulbis, B. (2010) Prevalence of Sickle Cell Disease in a Northeastern Region of the Democratic Republic of Congo: What Impact on Transfusion Policy? Transfusion Medicine, Screen, 20, 62-65. https://doi.org/10.1111/j.1365-3148.2009.00943.x

[53] Mutesa, L., Boemer, F., Ngendahayo, L., Rulisa, S., Rusingiza, E.K., Cwinya-Ay, N., Mazina, D., Kariyo, P.C., Bours, V. and Schoos, R. (2008) Neonatal Screening for Sickle Cell Disease in Central Africa: A Study of 1825 Newborns with a New Enzyme-Linked Immunosorbent Assay Test. Journal of Medical Screening, 14, 113-116. https://doi.org/10.1258/096914107782066211

[54] Arlene, S. (2008) Glycemic Control and Hemoglobinopathy: When A1C May Not Be Reliable. Diabetes Spectrum, 21, 46-49. https://doi.org/10.2337/diaspect.21.1.46

[55] O’Kane, M.J., Lynch, P.L., Moles, K.W. and Magee, S.E. (2001) Determination of a Diabetes Control and Complications Trial-Aligned $\mathrm{HbA(1c)}$ Reference Range in Pregnancy. Clinica Chimica Acta, 311, 157-159. https://doi.org/10.1016/S0009-8981(01)00579-4

[56] Nielsen, L.R., Ekbom, P., Damm, P., Glumer, C., Frandsen, M.M., Jensen, D.M. and Mathiesen, E.R. (2004) HbA1c Levels Are Significantly Lower in Early and Late Pregnancy. Diabetes Care, 27, 1200-1201. https://doi.org/10.2337/diacare.27.5.1200

[57] O’Connor, C., O’Shea, P.M., Owens, L.A., Carmody, L., Avalos, G., Nestor, L., Lydon, K. and Dunne, F. (2011) Trimester-Specific Reference Intervals for Haemoglobin A1c (HbA1c) in Pregnancy. Clinical Chemistry and Laboratory Medicine, 50, 905-909. https://doi.org/10.1515/cclm.2011.397

[58] Versantvoort, A.R., Roosmalen, V.J. and Radder, J.K. (2013) Course of HbA1c in Non-Diabetic Pregnancy Related to Birth Weight. The Netherlands Journal of Medicine, 71, 22-25.

[59] Jensen, D.M., Sorensen, B., Feilberg-Jorgensen, N., Westergaard, J.G. and Beck-Nielsen, H. (2000) Maternal and Perinatal Outcomes in 143 Danish Women with Gestational Diabetes Mellitus and 143 Controls with a Similar Risk Profile. Diabetic Medicine, 17, 281-286. https://doi.org/10.1046/j.1464-5491.2000.00268.x

[60] Shen, S.Y., Zhang, L.F., He, J.R., Lu, J.H., Chen, N.N., Xiao, W.Q., Yuan, M.Y., Xia, H.M., Lam, K.B.H. and Qiu, X. (2018) Association between Maternal Hyperglycemia and Composite Maternal-Birth Outcomes. Frontiers in Endocrinology, 9, 1-17. https://doi.org/10.3389/fendo.2018.00755

[61] Yang, H.X., Zhang, M.H., Sun, W.J. and Dong, Y. (2005) Associated Factors of Pre-Eclampsia Complicated in Pregnant Women with Abnormal Glucose Metabolism. Chinese Journal of Obstetrics and Gynecology, 40, 577-580.

[62] Barden, A., Singh, R., Walters, B.N., Ritchie, J., Roberman, B. and Beilin, L.J. (2004) Factors Predisposing to Pre-Eclampsia in Women with Gestational Diabetes. Journal of Hypertension, 22, 2371-2378. https://doi.org/10.1097/00004872-200412000-00020

[63] Gutaj, P., Zawiejska, A., Mantaj, U. and Wender-Ożegowska, E. (2017) Determinants of Preeclampsia in Women with Type 1 Diabetes. Acta Diabetologica, 54, 1115-1121. https://doi.org/10.1007/s00592-017-1053-3 
[64] Haiyan, Y., Xiaorong, Q. and Xiaodong, W. (2014) Application of Glycated Hemoglobin in the Perinatal Period. International Journal of Clinical and Experimental Medicine, 7, 4653-4659.

[65] Nielsen, G.L., Sørensen, H.T., Nielsen, P.H., Sabroe, S. and Olsen, J. (1997) Glycosylated Hemoglobin as Predictor of Adverse Fetal Outcome in Type 1 Diabetic Pregnancies. Acta Diabetologica, 34, 217-222. https://doi.org/10.1007/s005920050077

[66] Nielsen, G.L., Møller, M. and Sørensen, H.T. (2006) HbA1c in Early Diabetic Pregnancy and Pregnancy Outcomes: A Danish Population-Based Cohort Study of 573 Pregnancies in Women with Type 1 Diabetes. Diabetes Care, 29, 2612-2616. https://doi.org/10.2337/dc06-0914

[67] Jensen, D.M., Korsholm, L., Ovesen, P., Beck-Nielsen, H., Moelsted-Pedersen, L., Westergaard, J.G., Moeller, M. and Damm, P. (2009) Peri-Conceptional A1C and Risk of Serious Adverse Pregnancy Outcome in 933 Women with Type 1 Diabetes. Diabetes Care, 32, 1046-1048. https://doi.org/10.2337/dc08-2061

[68] Damm, P., Mersebach, H., Rastam, J., Kaaja, R., Hod, M., McCance, D.R. and Mathiesen, E.R. (2014) Poor Pregnancy Outcome in Women with Type 1 Diabetes Is Predicted by Elevated HbA1c and Spikes of High Glucose Values in the Third Trimester. The Journal of Maternal-Fetal \& Neonatal Medicine, 27, 149-154. https://doi.org/10.3109/14767058.2013.806896

[69] Tennant, P.W.G., Glinianaia, S.V., Bilous, R.W., Rankin, J. and Bell, R. (2014) Pre-Existing Diabetes, Maternal Glycated Haemoglobin, and the Risks of Fetal and Infant Death: A Population-Based Study. Diabetologia, 57, 285-294. https://doi.org/10.1007/s00125-013-3108-5

[70] Lowe, L.P., Metzger, B.E., Dyer, A.R., Lowe, J., McCance, D.R., Lappin, T.R., Trimble, E.R., Coustan, D.R., Hadden, D.R., Hod, M., Oats, J.J., Persson, B. and HAPO Study Cooperative Research Group (2012) Hyperglycemia and Adverse Pregnancy Outcome: Associations of Maternal A1C and Glucose with Pregnancy Outcomes. Diabetes Care, 35, 574-580. https://doi.org/10.2337/dc11-1687

[71] Capula, C., Mazza, T., Vero, R. and Costante, G. (2013) HbA1c Levels in Patients with Gestational Diabetes Mellitus: Relationship with Pre-Pregnancy BMI and Pregnancy Outcome. Journal of Endocrinological Investigation, 36, 1038-1045.

[72] Hughes, R.C, Moore, M.P., Gullam, J.E., Mohamed, K. and Rowan, J. (2014) An Early Pregnancy HbA1c 5.9\% (41 mmol/mol) Is Optimal for Detecting Diabetes and Identifies Women at Increased Risk of Adverse Pregnancy Outcomes. Diabetes Care, 37, 2953-2959. https://doi.org/10.2337/dc14-1312

[73] Cavero-Redondo, I., Barbara Peleteiro, B., Álvarez-Bueno, C., Rodriguez-Artalejo, F. and Martínez-Vizcaíno, V. (2017) Glycatedhaemoglobin A1c as a Risk Factor of Cardiovascular Outcomes and All-Cause Mortality in Diabetic and Non-Diabetic Populations: A Systematic Review and Meta-Analysis. BMJ Open, 7, 1-25. https://doi.org/10.1136/bmjopen-2017-015949

[74] National Collaborating Centre for Women's and Children's Health (UK) (2008) Management of Diabetes and Its Complications from Preconception to the Postnatal Period. In: Diabetes in Pregnancy, RCOG Press, London.

[75] American Diabetes Association (2014) Executive Summary: Standards of Medical Care in Diabetes-2014. Diabetes Care, 37, 5-13. https://doi.org/10.2337/dc14-S005

[76] Yu, Y., Jenkins, A.J., Nankervis, A.J., Hanssen, K.F., Scholz, H., Henriksen, T., Lorentzen, B., Clausen, T., Garg, S.K., Menard, M.K., Hammad, S.M., Scardo, J.C., Stanley, J.R., Dashti, A., May, K., Lu, K., Aston, C.E., Wang, J.J., Zhang, S.X., Ma, 
J.X. and Lyons, T.J. (2009) Anti-Angiogenic Factors and Preeclampsia in Type 1 Diabetic Women. Diabetologia, 52, 160-168. https://doi.org/10.1007/s00125-008-1182-x

[77] Asadifar, M., Bakhti, M., Habibi-Rezaei, M., Moosavi-Movahedi, A.A., Tabatabi, M.R., Ahmadinejad, M. and Badlou, B.A. (2015) Platelet Aggregation Increased by Advanced Glycated Hemoglobin. Journal of Blood Disorders \& Transfusion, 6, 293. https://doi.org/10.4172/2155-9864.1000293

[78] Younessi, P. and Yoonessi, A. (2011) Advanced Glycation End-Products and Their Receptor-Mediated Roles: Inflammation and Oxidative Stress. Iranian Journal of Medical Sciences, 36, 154-166.

[79] Braga, F.O., Negrato, C.A., Bevilacqua da Matta, M.F., Carneiro, J.R.I. and Gomes, M.B. (2019) Relationship between Inflammatory Markers, Glycated Hemoglobin and Placental Weight on Fetal Outcomes in Women with Gestational Diabetes. Archives of Endocrinology and Metabolism, 63, 1. https://doi.org/10.20945/2359-3997000000099

[80] Mortada, R., Kallail, K.J., Dong, F. and Karakas, S. (2015) HbA1c in Patients with Polycystic Ovary Syndrome: A Potential Marker of Inflammation. Journal of Reproduction \& Infertility, 16, 203-206.

[81] Cooke, C.L., Brockelsby, J.C., Baker, P.N. and Davidge, S.T. (2003) The Receptor for Advanced Glycation End Products (RAGE) Is Elevated in Women with Preeclampsia. Hypertension in Pregnancy, 22, 173-184. https://doi.org/10.1081/PRG-120021068

[82] Xian, N., Chen, W., Zhang, Y., Li, J., Zhang, N. and Ye, Y. (2015) Correlation of the Expressions of Advanced Glycation End Products and Its Receptor in Serum and Placenta with the Pathogenesis of Preeclampsia. Chinese Journal of Obstetrics and Gynecology, 50, 493-499.

[83] Merviel, P., Touzart, L., Deslandes,V., Delmas, M., Coicaud, M. and Gondry, J. (2008) Facteurs de risque de la prééclampsie en cas de grossesse unique. Journal de Gynécologie Obstétrique et Biologie de la Reproduction, 37, 477-482. https://doi.org/10.1016/j.jgyn.2008.04.001

[84] English, F.A., Kenny, L.C. and McCarthy, F. (2015) Risk Factors and Effective Management of Preeclampsia. Integrated Blood Pressure Control, 8, 7-12. https://doi.org/10.2147/IBPC.S50641

[85] Cisse, C.T., Thiam, M., Diagne, P.M. and Moreau, J.C. (2005) Prééclampsie en milieu africain: Epidémiologie et pronostic au CHU de Dakar. Gynéco venue d ailleurs, 301, 1-6.

[86] Mohamed, M.S., Sass, S., Zein, A., Lbarae, A., Khadmaoui, A., Lrhorfi, L.A., Oumaima, O. and Bengueddour, R. (2017) Etude prospective du profil épidémiologique des femmes enceintes pré-éclamptiques en Mauritanie. European Scientific Journal, 13, 124-131. https://doi.org/10.19044/esj.2017.v13n36p124

[87] Bdolah, Y., Lam, C., Rajakumar, A., Shivalingappa, V., Mutter, W., Sachs, B.P., Lim, K.H., Bdolah-Abram, T., Epstein, F.H. and Karumanchi, S.A. (2008) Twin Pregnancy and the Risk of Preeclampsia: Bigger Placenta or Relative Ischemia? American Journal of Obstetrics \& Gynecology, 198, 1-6. https://doi.org/10.1016/j.ajog.2007.10.783

[88] Umadia, O.C., Dimuthu, V.D., Henares, J.G., Thilaganathan, B. and Khalil, A. (2016) 36 Risk Factors and Outcomes of Preeclampsia in Twin Pregnancies: Risk Factors, Prediction of Preeclampsia. Pregnancy Hypertension: An International Journal of Women's Cardiovascular Health, 6, 153-154. https://doi.org/10.1016/j.preghy.2016.08.037 
[89] Simmons, D. and Yapa, M. (2002) Association between Twin Pregnancy and Hyperglycemia in a Multiethnic Community in New Zealand. Diabetes Care, 25, 934-935. https://doi.org/10.2337/diacare.25.5.934

[90] Dwyer, P.L. and Oats, J.N. (1982) Glucose Intolerance in Twin Pregnancy. Australian and New Zealand Journal of Obstetrics and Gynaecology, 22, 131-135. https://doi.org/10.1111/j.1479-828X.1982.tb01425.x

[91] Ekbom, P., Damm, P., Feldt-Rasmussen, B., Feldt-Rasmussen, U., Jensen, D.M. and Mathiesen, E.R. (2008) Elevated Third-Trimester Haemoglobin A 1c Predicts Preterm Delivery in Type 1 Diabetes. Journal of Diabetes and Its Complications, 22, 297-302. https://doi.org/10.1016/j.jdiacomp.2007.03.008

[92] Liu, S., James, M.H., Robert, J.C., Li, S. and Vivian, A.F. (2015) Association between Inflammation and Biological Variation in Hemoglobin A1c in U.S. Nondiabetic Adults. The Journal of Clinical Endocrinology \& Metabolism, 100, 2364-2371. https://doi.org/10.1210/jc.2014-4454

[93] Wu, T., Dorn, J.P., Donahue, R.P., Sempos, C.T. and Trevisan, M. (2002) Associations of Serum C-Reactive Protein with Fasting Insulin, Glucose and Glycosylated Hemoglobin: The Third National Health and Nutrition Examination Survey, 19881994. American Journal of Epidemiology, 155, 65-71. https://doi.org/10.1093/aje/155.1.65

[94] Sushma, B.J. and Shrikant, C. (2016) Study of Serum High Sensitivity C-Reactive Protein, Ferritin and Glycated Hemoglobin Levels in Patients with Type 2 Diabetes Mellitus. International Journal of Science and Research, 5, 2177-2182. https://doi.org/10.21275/v5i6.NOV164805

[95] Mihu, D., Razvan, C., Malutan, A. and Mihaela, C. (2015) Evaluation of Maternal Systemic Inflammatory Response in Preeclampsia. Taiwanese Journal of Obstetrics and Gynecology, 54, 160-166. https://doi.org/10.1016/j.tjog.2014.03.006

[96] Harmon, A.C., Cornelius, D.C., Amaral, L.M., Faulkner, J.L., Cunningham Jr., M.W., Wallace, K. and LaMarca, B. (2016) The Role of Inflammation in the Pathology of Preeclampsia. Clinical Science, 130, 409-419. https://doi.org/10.1042/CS20150702

[97] Black, K.D. and Horowitz, J.A. (2018) Inflammatory Markers and Preeclampsia: A Systematic Review. Nursing Research, 67, 242-251. https://doi.org/10.1097/NNR.0000000000000285

[98] Perucci, L.O., Corrêa, M.D., Dusse, L.M., Gomes, K.B. and Sousa, L.P. (2017) Resolution of inflammation pathways in Preeclampsia-A Narrative Review. Immunologic Research, 65, 774-789. https://doi.org/10.1007/s12026-017-8921-3

[99] Sibai, B.M., Taslimi, M.M, El-Nazer, A., Amon, E., Mabie, B.C. and Ryan, G.M. (1986) Maternal-Perinatal Outcome Associated with the Syndrome of Hemolysis, Elevated Liver Enzymes, and Low Platelets in Severe Preeclampsia-Eclampsia. American Journal of Obstetrics \& Gynecology, 155, 501-509. https://doi.org/10.1016/0002-9378(86)90266-8

[100] Reubinoff, B.E. and Schenker, J.G. (1991) HELLP Syndrome-A Syndrome of Hemolysis, Elevated Liver Enzymes and Low Platelet Count-Complicating Preeclampsia-Eclampsia. International Journal of Gynecology \& Obstetrics, 36, 95-102. https://doi.org/10.1016/0020-7292(91)90762-T

[101] Abildgaard, U. and Heimdal, K. (2013) Pathogenesis of the Syndrome of Hemolysis, Elevated Liver Enzymes, and Low Platelet Count (HELLP): A Review. European Journal of Obstetrics \& Gynecology and Reproductive Biology, 166, 117-123. https://doi.org/10.1016/j.ejogrb.2012.09.026 